\title{
Examination of conceptual structures of science preservice teachers about metabolic events and energy forms in the cell
}

\author{
Yeter Simsekli \\ Education Faculty, Uludag University, 16059, Bursa, Turkey \\ For correspondence: ysimsekli@uludag.edu.tr
}

\begin{abstract}
In this study, it was aimed to examine the science preservice teachers' conceptual structures about the metabolic events taking place and the forms of energy in a cell. In the study, the descriptive model was used. In the study carried out during the spring semester of the 2017-2018 academic year participated a total of 123 third and fourth year preservice teachers studying at Science Education Division of the Education Faculty of Uludag University. The preservice teachers were asked to write down the metabolic events taking place and the forms of energy in the cell. The documents belonging to the preservice teachers composed the qualitative data of the study. In the data analysis process, since 13 of the preservice teachers did not write any answers, the documents belonging to 110 preservice teachers were taken into evaluation. As a result of the analysis of the documents, a total of 306 answers were obtained, 186 of them were related to the metabolic events and 120 of them were related to the forms of energy. In the data analysis, the content analysis method was used. The data sets belonging to the frequencies and the percentages of the metabolic events and forms of energy specified by the preservice teachers were transformed into tables and graphs. According to the results, a great majority of the preservice teachers' conceptual structures related to the metabolic events were limited to respiration and photosynthesis and those which were related to the energy forms were limited to ATP, light and heat.
\end{abstract}

Keywords: Cell, metabolic events, energy forms, science, preservice teacher

\section{Introduction}

Cell is the first step of the topics of the field of biology in physical sciences. For this reason, a comprehensive learning of cell will facilitate the learning of subsequent topics. With this thought, studies have been made on more effective and permanent teaching of the topic of cell. Saygin et al. (2006) determined that the constructivist teaching approach used in the teaching of the topic of cell increased the learning success. Uşak (2009) investigated the science and technology preservice teachers' pedagogical content knowledge about the topic of cell and determined that they were more teacher-centered in terms of teaching approaches. Köse (2014) examined the effect of the use of concept maps in the teaching of the topics of cell and organelles on the students' success levels and reached the result that the teaching with concept maps was more useful. Pekel and Maytar (2016) investigated the effect of the computer-assisted instruction method based on the constructivist approach used in the teaching of the topic of cell biology on academic success and determined as a result of the study that the computer-assisted learning method affected the students' academic achievement levels in relation to the topic of cell biology positively. In the curriculum, the topic of cell is examined comprehensively in the 9th grade. For this reason, most of the studies on the teaching of the topic of cell are made with high school students.

However, in secondary school, as it is required by the nature of students, the topic of cell is taught rather shallowly. In the teaching of the topic of cell in secondary school, besides mostly preferred pictures and models, highlighting the living characteristic of the cell (i.e., events taking place in the 
cell) by using different teaching methods (game, drama, video, analogy, laboratory, etc.) (Pekel and Maytar, 2016; Şahinet al., 2017) may provide important contribution to students' interest in not only science but also the science of biology. For this reason, it is necessary that science teachers should have a command of the topic of cell in addition to knowing special teaching methods well and accurate and complete knowledge about the concepts related to the metabolic events taking place in the living cell and forms of energy used or released in these events and also interconceptual relationships (Morgil and Yılmaz, 1999; Kurtuluş and Çavdar, 2010; Balbağ and Karaer, 2016; Altunoğlu and Hançer, 2017).

Teachers play an important role in students' learning concepts (Kurt and Ekici, 2013). Concepts constitute building stones of pieces of knowledge and interconceptual relationships form scientific principles. In physical sciences, both topics and concepts and principles examined in a topic have been classified in a hierarchical manner. Comprehension of this hierarchical order between concepts facilitates learning and teaching of that area of science (Çepni et al., 1997).

A teacher sufficiently knowledgeable of the concepts related to the cell may behave more assiduously and willingly about trying different teaching methods. And different teaching methods will attract the interest of different students in the topic. In this context, the aim of this study is to examine the science preservice teachers' conceptual structures in relation to the metabolic events taking place and forms of energy used or released in the cell. For this purpose, in the study, answers were sought to the following questions:

What are the science preservice teachers' conceptual structures in relation to the metabolic events taking place in the cell?

What are the science preservice teachers' conceptual structures in relation to the forms of energy used or released in the cell?

How do the science preservice teachers relate the metabolic events taking place and the forms of energy used or released in the cell?

\section{Material and Method}

Research Model

In the study, the descriptive model was used. In the descriptive model, it is aimed to describe an existing situation and a research topic is defined within its own conditions without making any change (Karasar, 2005).

\section{Research Sample}

The research sample was composed of the science preservice teachers. In the study, the convenience sampling method was used. In the study carried out during the spring semester of the 2017-2018 academic yearparticipated 123 third and fourth year preservice teachers taking education at the Science Education Division of the Mathematics and Science Education Departments of the Education Faculty of Uludag University. The preservice teachers were made necessary explanations prior to the study and told that the results to be obtained from the study would not affect their course grades.

\section{Data Collection Tools}

In the study, the science preservice teachers were asked to write down the metabolic events taking place and the forms of energy used or released in the cell. In science education, writing is described as a method developing reasoning and supporting the presentation of personal opinions about scientific explanations and logical thinking (Prain \& Hand, 2006). The documents belonging to the preservice 
teachers were examined by giving numbers. The document analysis includes the analysis of written materials which are useful for collecting data. In a qualitative study, the document analysis method can be used as a data collection method (Yıldırım and Şimşek, 2008).

\section{Data Analysis}

In the analysis of the data obtained qualitatively in the study, the content analysis method was used. In the content analysis, firstly, sets of obtained data are conceptualized, then, they are reasonably organized according to emerging concepts and, finally, themes explaining sets of data are determined in accordance with this (Yıldırım and Şimşek, 2008). In the study, the documents written by the preservice teachers were analyzed and since 13 of the preservice teachers did not write any answers or wrote irrelevant answers, the documents belonging to 110 preservice teachers were taken into evaluation. The answers belonging to the documents taken into evaluation were examined and a total of 306 answers were obtained, 186 were related to the metabolic events and 120 were related to the forms of energy.

Such headings written by the preservice teachers as "Photosynthesis", "Chemosynthesis", "Protein Synthesis" and "Anabolic Reactions" were arranged as sub-headings under the heading of anabolic reactions and such headings as "Respiration", "ATP Hydrolysis" and "Catabolic Reactions" were arranged as sub-headings under the heading of catabolic reactions. Again, such headings as "Heat", "Light", "ATP", "Chemical energy" written by the preservice teachers for each metabolic event were arranged under the heading of forms of energy used or released. The frequency and the percentage values of the sets of data related to the sub-headings belonging to the metabolic events specified by the preservice teachers and the frequency and the percentage values of the sets of data related to the heading of forms of energy used or released were given in tables.

With the aim of achieving the validity of research results, the documents were coded and the examples were selected from among the preservice teachers' opinions supposed to be best representing the obtained categories and interpreted in the 'findings' section (Yıldırım and Şimşek, 2006). Moreover, in order to achieve the reliability of the study, another researcher was asked to give support and the sets of data obtained in the study were compared.

\section{Results}

In this study aiming to examine the science preservice teachers' conceptual structures in relation to the metabolic events taking place and forms of energy used or released in the cell, the sets of data obtained from the documents belonging to the preservice teachers were gathered under two headings, namely metabolic events and forms of energy. A total of 306 answers, 186 about metabolic events and 120 about forms of energy were obtained.

The sets of data gathered under the heading of metabolic events (186 answers) with the aim of examining the preservice teachers' conceptual structures in relation to metabolic events taking place in the cell were also evaluated under two headings, namely anabolic reactions and catabolic reactions. The frequency and percentage values belonging to the heading of anabolic and catabolic reactions were shown in Table 1.

When Table 1 was examined, it was determined that the preservice teachers wrote 'photosynthesis', 'chemosynthesis' and 'protein synthesis' without describing them as anabolic reactions; moreover, some of them $(18,18 \%)$ wrote 'anabolic reactions' in general. 
Table 1.Frequency and percentage values belonging to the sub-headings examined under the heading of anabolic and catabolic reactions

\begin{tabular}{llcc}
\hline Metabolicevents & Sub-headings & F & $\%$ \\
\hline Anabolic reactions & Photosynthesis & 52 & 47.2 \\
& Chemosynthesis & 4 & 3.63 \\
& Protein synthesis & 4 & 3.63 \\
& Anabolic reactions & 20 & 18.18 \\
Catabolic reactions & 82 & 74.5 \\
& Respiration & 2 & 1.8 \\
& ATP hydrolysis & 22 & 20 \\
\hline
\end{tabular}

Below are given some examples from the preservice teachers' explanations about the concepts examined under the heading of anabolic reactions. In this scope, it was determined that while $47,2 \%$ of the preservice teachers wrote a statement about photosynthesis, very few of them wrote statements about chemosynthesis $(3,63 \%)$ and protein synthesis $(3.63 \%)$.

"And in plants, photosynthesis is observed as a metabolic event." (PT 31)

"Chemosynthetic living beings chemosynthesize." (PT39)

"The metabolic events taking place in the cell are anabolic and catabolic reactions." (PT 36)

In the second section of Table 1,it is observed that the preservice teaches wrote 'respiration' and 'ATP hydrolysis' without describing them as catabolic reactions and some of them $(20 \%)$ wrote 'catabolic reactions' in general. Below are given some examples from the preservice teachers' explanations about the concepts examined under the heading of catabolic reactions. In this scope, it was determined that while $74,5 \%$ of the preservice teachers wrote a statement about respiration, very few of them $(1,8 \%)$ wrote a statement about ATP hydrolysis.

"Respiration is a metabolic event during which glucose reacts with oxygen and, together with water and carbon dioxide, ATP is released as a result." (PT52)

"During metaboli cevents, ATP is catabolized and transformed into AD." (PT67)

"By metabolic events, we mean anabolic and catabolic reactions." (PT91)

The frequencies and the percentages of the sets of data (120 answers) related to the preservice teachers' conceptual structures in relation to the sub-headings examined under the heading of forms of energy used or released in the cell were shown in Table 2.

Table 2.Frequency and percentage values related to the sub-headings examined under the heading of energy forms

\begin{tabular}{lcc}
\hline Energy forms & F & $\%$ \\
\hline ATP & 52 & 47.2 \\
Light & 32 & 29.1 \\
Chemical energy & 28 & 26 \\
Heat & 8 & 7.2 \\
\hline
\end{tabular}

As it is seen in Table 2,the forms of energy used or released were gathered under four headings and it was determined that the preservice teachers wrote 'ATP', 'light', 'chemical energy'and 'heat'. Below were given some examples from the preservice teachers' explanations about their concepts examined 
under the heading of forms of energy. In this scope, it was determined that while $42,7 \%$ of the preservice teachers wrote statements about ATP, 29.1\%wrote statements about light, $26 \%$ about chemical energy and few of them $(7,2 \%)$ about heat.

"The energy used during the metabolic events taking place in the cell is ATP." (PT 87)

"As a result of respiration, the ATP energy is released." (PT 21)

"Plants photosynthesize and their energysource is sunlight." (PT74)

"As a result of metabolic events, chemical energy is released." (PT107)

"Nutrient is burnt via oxygen and the heat energy is released." (PT27)

The frequency values belonging to the sub-headings examined under the heading of Metabolic Events and Energy Forms were shown in Graph 1.

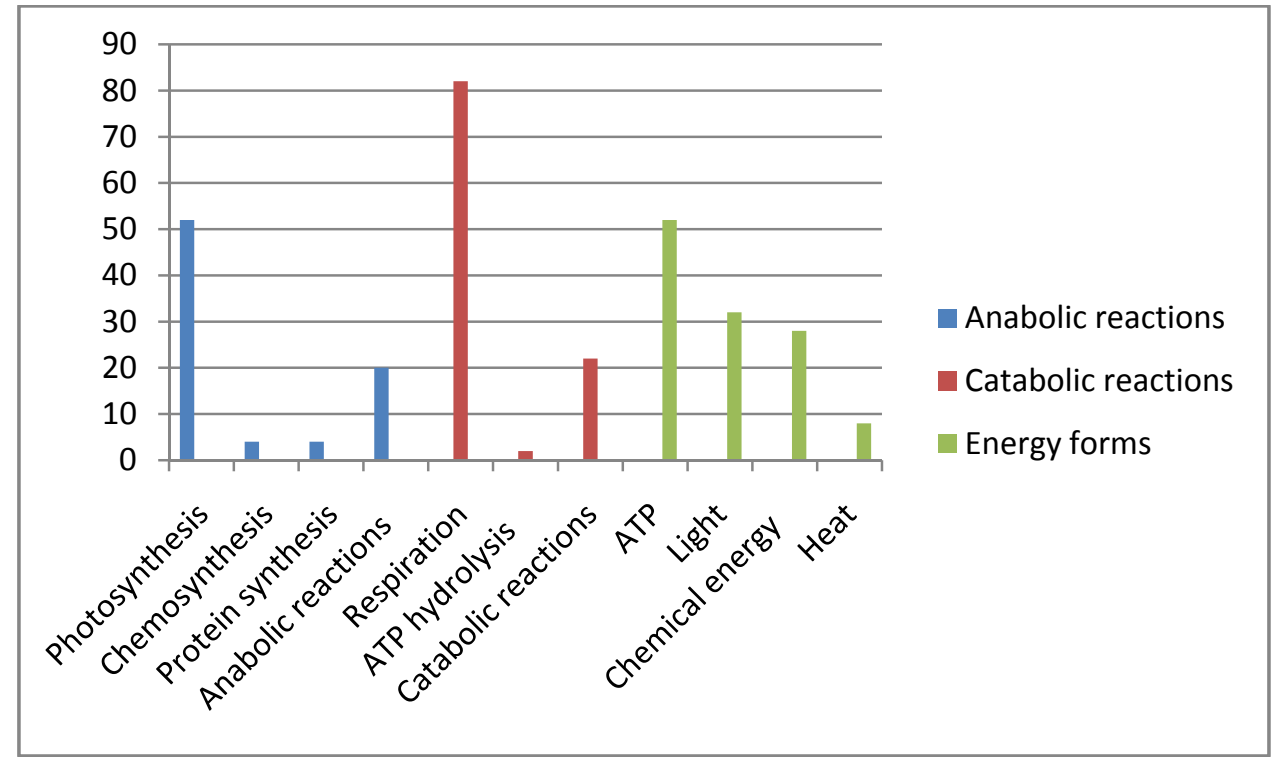

Graph 1. Frequency values belonging to the sub-headings examined under the heading of metabolic events and energy forms

When Graph 1 is examined, it is seen that the event of photosynthesis is attracting attention under the heading of anabolic reactions, one of the metabolicevents, the event of respiration is eye-catching under the heading of catabolic reactions and ATP and light are emphasized under the heading of energy forms.

The frequency and percentage values belonging to the energy forms used or released in metabolic events written by the preservice teachers participated in the study carried out with the aim of examining how science preservice teachers relate metabolic events and energy forms in a cell were shown in Table 3.

Table 3.Frequency and percentage values related to the energy forms belonging to the metabolic events

\begin{tabular}{llcclcc}
\hline $\begin{array}{l}\text { Metabolic } \\
\text { events }\end{array}$ & Sub-categories & F & $\%$ & $\begin{array}{l}\text { Forms of energy } \\
\text { sub-categories }\end{array}$ & F & $\%$ \\
\hline Anabolic & Photosynthesis & 52 & 47.2 & Light & 32 & 29.1
\end{tabular}




\begin{tabular}{llcclcc} 
reactions & Chemosynthesis & 4 & 3.63 & ---- & ---- & ---- \\
& Protein Synthesis & 4 & 3.63 & ATP & 2 & 1.8 \\
& Anabolic reactions & 20 & 18.18 & Chemical energy & 4 & 3.6 \\
Catabolic & Respiration & 82 & 74.5 & ATP & 50 & 45.4 \\
reactions & & & & Heat & 8 & 7.2 \\
& & 2 & & Chemical energy & 20 & 18.18 \\
& ATP hydrolysis & 22 & 20 & Chemical energy & -4 & 3.6 \\
& $\begin{array}{l}\text { Catabolic } \\
\text { reactions }\end{array}$ & & & & & \\
\hline
\end{tabular}

When Table 3 was examined in terms of the forms of energy used or released in the metabolic events, it was observed that the preservice teachers wrote that light $(29,1 \%)$ was used in the event of photosynthesis examined under the heading of anabolic reactions, ATP $(1,8 \%)$ was used in protein synthesis, but they did not write anything about chemosynthesis. Moreover, it was determined that few of the preservice teachers generally writing 'anabolic reactions' wrote 'chemical energy' as a form of energy $(3,6 \%)$. Below were given some examples from the preservice teachers' explanations about the energy forms which they related to the sub-headings examined under the heading of anabolic reactions.

"If we take a plant cell, it photosynthesizes thanks to light energy." (PT13)

"The metabolic events which take place in the cell are respiration, protein synthesis ........the ATP energy is used in synthesis events." (PT21)

It was determined that while $45,4 \%$ of the preservice teachers wrote that ATP, $7,2 \%$ wrote that heat and $18,18 \%$ wrote that chemical energy was released as a result of the event of respiration examined under the heading of catabolic reactions, they did not write anything about ATP hydrolysis. Moreover, few of the preservice teachers generally writing 'catabolic reactions' wrote 'chemical energy' as a form of energy $(3,6 \%)$.Below were given some examples from the preservice teachers' explanations about the energy forms which they related to the sub-headings examined under the heading of catabolic reactions.

"During respiration, the ATP energy is released." (PT31)

"Nutrient is burnt via oxygen and the heat energy is released." (PT27)

"Nutrient is catabolized as a result of catabolic events and chemical energy is obtained." (PT13)

\section{Discussion}

According to the results obtained in this study aiming to examine the science preservice teachers' conceptual structures about the metabolic events taking place or the energy forms used or released in the cell, it can be stated that most of the preservice teachers could not categorize metabolic events into anabolic and catabolic reactions and the ones who wrote 'anabolic and catabolic reactions' could not identify the type of the reaction. It was observed that while the preservice teachers wrote 'photosynthesis', 'chemosynthesis' and 'protein synthesis', three of the anabolic reactions taking place in the cell, nearly more than half of them did not write 'photosynthesis' and only a few of them wrote 'chemosynthesis' and 'protein synthesis'. It is attracting attention that while the preservice teachers wrote 'respiration' and 'ATP hydrolysis', two of the catabolic reactions, and nearly three fourth of them wrote 'respiration', only two preservice teachers wrote 'ATP hydrolysis'. It was observed that the preservice teachers wrote 'ATP', 'light' and 'heat' as a form of energy; it was determined when it 
was examined quantitatively that nearly half of them wrote 'ATP', $29 \%$ of them wrote 'light' and very few of them wrote 'heat'.

When the set of data related to the forms of energy used or released in metabolic events written by the science preservice teachers with the aim of examining how they related metabolic events and forms of energy in the cell were examined, it was observed that $29,1 \%$ of them wrote 'light' in the event of photosynthesis examined under the heading of anabolic reactions, $1,8 \%$ of them wrote 'ATP is used in protein synthesis', but they did not write anything about chemosynthesis. It was determined that while $45,4 \%$ of the preservice teachers wrote 'ATP' is released as a result of respiration examined under the heading of catabolic reactions' and $7,2 \%$ of them wrote 'heat is released', they did not write anything for ATP hydrolysis. Moreover, when the sets of numerical data in the table were examined, it was observed that while nearly half of the preservice teachers wrote "photosynthesis" under the heading of anabolic reactions, about 30\% of them wrote "light" as a form of energy used, about $75 \%$ of them wrote "respiration" under the heading of catabolic reactions, $45 \%$ wrote "ATP" as a form of energy released.

Based on these results, it can be stated that the preservice teachers' conceptual levels in relation to metabolic events were limited to respiration and photosynthesis and their conceptual levels in relation to the energy forms used or released in these events were limited to ATP, light and heat. These findings show parallelism with those of the studies on science teachers' pedagogical content knowledge (Uşak, 2009; Çavaş and Kesercioğlu, 2010; Önelet al., 2015; Balbağet al., 2016;).

In summary, it was determined that the preservice teachers did not have comprehensive knowledge about metabolic events and energy forms used in the cell and, hence, they were incompetent at relating metabolic events with energy forms used or released in these events.

\section{References}

Akgündüz, D. Bal, Ş., (2013). İlköğretim fen bilgisi dersi 6.sınıf biyoloji konularında kavram haritalarının kullanılmasının öğrencilerin akademik başarılarına ve tutumlarına etkisi. 21. Yüzyılda Ĕ̆itim ve Toplum, 3(5) 86-96.

Altunoğlu, A., Hançer, H., (2017). Science teachers' level of technological pedagogical content knowledge and research of their attitudes toward to the technology. Journal Of Social And Humanities Sciences Research, 4(13), 1536-1546.

Balbağ, M.Z., Karaer, G., (2016). Fen bilgisi öğretmenlerinin fen öğretiminde karşllaştıklar sorunlara yönelik öğretmen görüşleri. Ĕ̆itim ve Öğretim Araştırmaları Dergisi, 5 (3), 1-11.

Balbağ, M.Z., Leblebicier, K., Karaer, G., Sarıkahya, E., Erkan, Ö.,(2016). Türkiye'de fen eğitimi ve öğretimi sorunları. Eğitim ve Öğretim Araştırmaları Dergisi, 5 (3), 12-23.

Cavaş, B., Kesercioğlu, T., (2010).A qualitative study on student' understanding and misconceptions regarding the living cell. New World Sciences Academy Education Sciences, 5, (1), 321-331.

Çepni, S., Ayas, A., Johnson, D., Turgut, F., (1997).Fizik öğretimi. YÖK/Dünya Bankası, Milli Eğitimi geliştirme Projesi, Hizmet Öncesi Öğretmen Egitimi, Ankara.

Karasar, N., (2005). Bilimsel araştırma yöntemi. Ankara: Nobel Yayınevi.

Kurt, H., Ekici, G., (2013). Determining biology student teachers' cognitive structure and alternative concepts on the concept of "bacteria", Turkish Studies,8(8), 885-910.

Kurtuluş, N. Çavdar, O., (2010). Öğretmen adaylarının fen öğretimine yönelik öz yeterlilikleri. New World Sciences Academy Education Sciences, 5(3), 1302-1315.

Morgil, F. İ., Yılmaz, A., (1999). Fen ögretmeninin görevleri ve nitelikleri, fen öğretmeni yetiştirilmesine yönelik öneriler. Hacettepe Üniversitesi Eğitim Fakültesi Dergisi, $15: 181$ - 186.

Önel,A., Yüce, Z., Yeşilyurt, D.,(2015). Fen bilgisi öğretmen adaylarının hücre konusundaki kavramsal bilgi düzeylerinin çizimler yoluyla belirlenmesi, Caucasian Journal of Science, 2(1), 32-43.

ÖzayKöse, E., (2014).Hücre ve organ ellerin öğretiminde kavram haritalarının kullanılması. Uluslararası Türk Eğitim Bilimleri Dergisi, 3,116-121.

Pekel, H., Maytar, F.(2016). Hücre biyolojisi konusunun öğretiminde kullanılan yapılandırmacı yaklaşıma dayalı bilgisayar destekli öğretim yönteminin akademik başarı üzerine etkisi. International Journal of Active Learning,1(2), 21-37.

Prain, V. \& Hand, B., (2006).Science and Literacy. In K. Appleton (Ed.), Elementary Science Teacher Education: Issues and Practice (pp. 153-174). Mahwah, NJ: Association of Educators of Science Teachers publication. Lawrence Erlbaum Associates, Inc. 
Saygın, Ö.,Atılboz, N.G., Salman, S., (2006).

Yapılandırmacıöğretimyaklaşımınınbiyolojidersikonularınıöğrenmebaşarısıüzerineetkisi: canlılığın temel birimi-hücre, Gazi Ĕ̆itim Fakültesi Dergisi, 26(1), 51-64.

Şahin, Ç., Akan, G., Naldemir, T., Dikgöz, K., (2017, Mayıs). Hücre polyoyununun tanıtılması ve oyun hakkında öğretmen ve öğrenci görüşleri. IV the International Eurasian Educational Research Congress, Denizli.

Uşak, M., (2009).Preservice science and technology teachers' pedagogical content knowledge on cell topics. Kuram ve

Uygulamada Eğitim Bilimleri / Educational Sciences: Theory \& Practice, 9(4), 2033-2046.

Yıldırım, A., Şimşek, H., (2006). Sosyal bilimlerde nitel araştırma yöntemleri. Ankara: Seçkin.

Note: This study was presented at the 2nd National Conference on Biology Education held in Aksaray, Turkey on 03-05 July 2018 and Short abstract of this paper was published Conference Proceedings book in July 2018. 